\title{
Alaskan Submarine Cables: A Struggle with a Harsh Environment
}

\author{
BRUCE C. HEEZEN ${ }^{1}$ AND G. LEONARD JOHNSON ${ }^{2}$
}

\begin{abstract}
The Alaskan cable system at one time included 86 submarine telegraph cables stretching from Puget Sound northward through the Alaskan Panhandle and thence westward into the Aleutian Island Arc. Cable failures in this system reveal dynamic natural forces affecting the sea floor. The cable failures can primarily be attributed in straits on the continental shelf and upper continental slope to chafe by bottom currents, and off the mouths of major streams to turbidity currents and gravitational slides.
\end{abstract}

RÉSUMÉ. Les câbles sous-marins en Alaska, une lutte contre un milieu difficile. A un moment donné, le système de communications de l'Alaska comprenait 86 câbles télégraphiques sous-marins, s'étendant du Puget Sound vers le nord à travers l'Alaska côtier, puis vers l'Ouest jusqu'à l'arc des Aléoutiennes. Les pannes de ces câbles sont révélatrices des forces dynamiques naturelles qui affectent le fond des mers. Dans les détroits du plateau continental et de la partie supérieure du.talus continenta1, les bris s'explíquent par le frottement dû aux courants profonds : à l'embouchure des grands cours d'eau, ils sont provoqués par les courants de turbidité et les glissements sous-marins.

PЕЗЮМЕ. Подводные кабели на Аляске - боръба с суровой природой. Кабельнал система на Аляске насчитывала в свое время 86 подводных телеграфных кабелей, проложенных на север от залива Пугет вдоль южното побережья Аляски и далее на запад по направлению к Алеутским островам. Поломки кабелей свидетельствуют о наличии естественных динамических процессов на дне моря. В проливах на континентальном шельфе и верхней части континентального склона, поломки вызываются, главным образом, донными течениями, а вблизи устьев больпих рек - мутными потоками и гравитационными оползнями.

\section{INTRODUCTION}

In May 1900 the Congress of the United States directed that a telegraph and cable communication system linking the principal military and commercial centres of Alaska be established by the War Department. In October of the same year the first 133-mile section of submarine cable was laid on the Continental Shelf between Nome and St. Michael. In August 1901 the cable system was expanded within the inland waters to link the panhandle settlements of Skagway, Haines and Juneau, and in 1904 the system was further extended across the open ocean to Seattle on the south and to Valdez on the north. Minor changes were made in the ensuing years; cables were renewed and various links were added to the system until June 1940 when the entire cable network was abandoned (Fig. 1). Only one year later the war necessitated a rapid rebirth of the system and further

1Lamont Geological Observatory, Columbia University, Palisades, New York.

2Present address: Global Ocean Floor Analysis and Research Center, USN Oceanographic Office. 

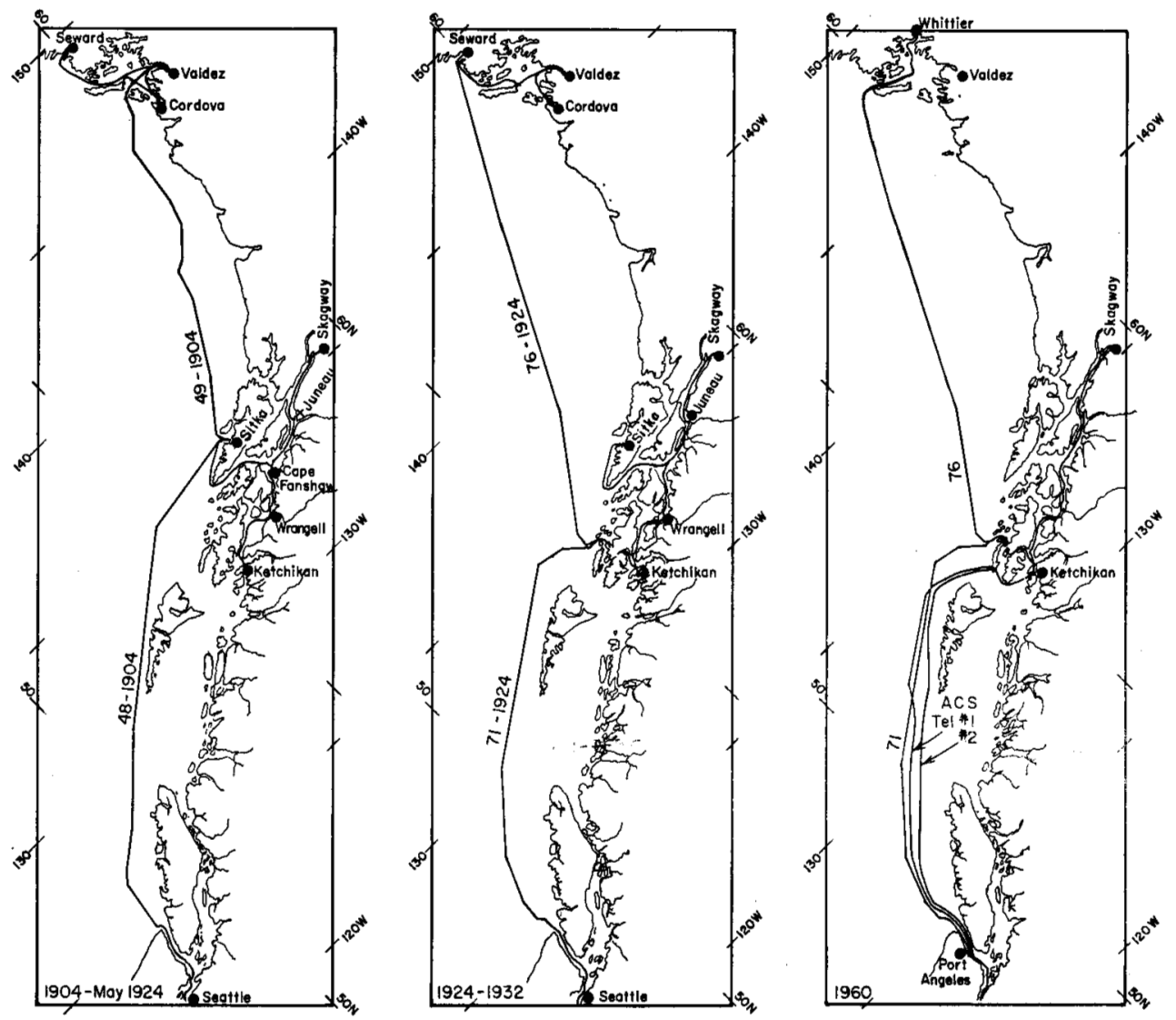

FIG. 1. Extent of Alaskan cable system. Dates refer to date of laying of the submarine cable. Numbers are the assigned cable numbers, i.e. cable 48: Seattle-Sitka.

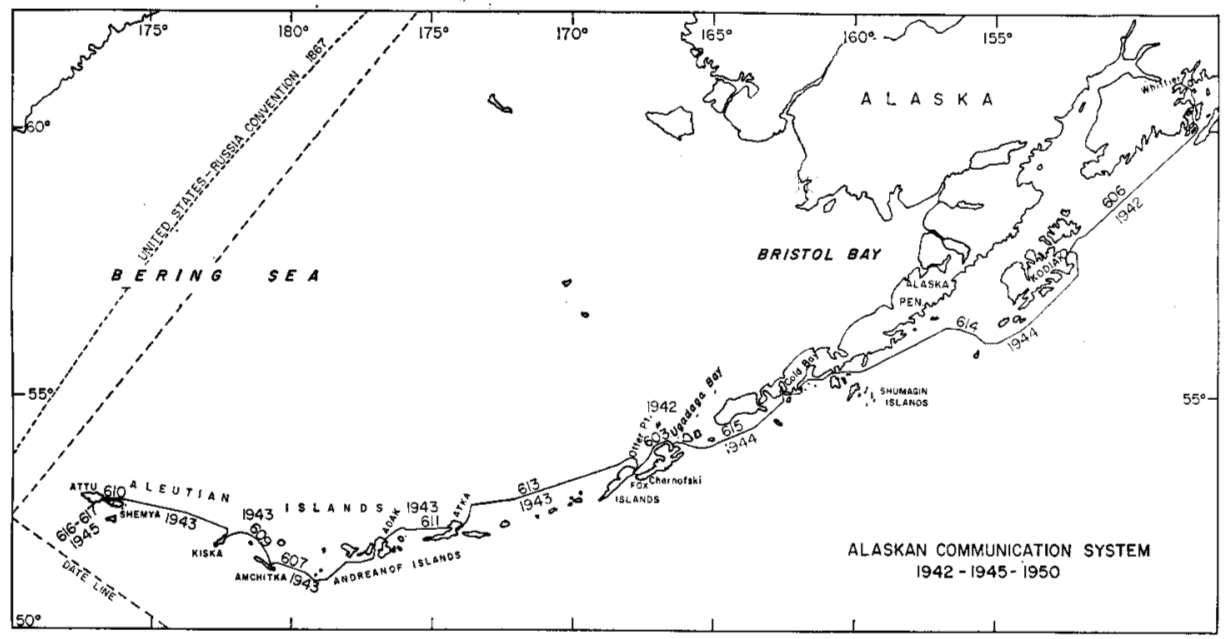

FIG. 2. Extent of the Alaskan cable system in the Aleutians. Dates refer to date of laying of the submarine cable. 
extension into the Aleutian Island arc (Fig. 2). However, by the year 1950 all of the new Aleutian cables, having served their war time need, had been abandoned and, by 1960 , most of the remaining telegraph cables of the system were no longer maintained. However, a telephone cable laid in 1956 linking Seattle, Ketchikan, Juneau and Skagway, is still in operation (Heezen and Johnson, 1966).

The marine environment in Alaskan waters treated the cables harshly, and the history of their repair and maintenance reveals much concerning the geological agents at work on the sea floor.

Animals as well as the physical environment pose threats to the cables. Toothed whales dive deeply and root in the bottom sediments at depths of at least 600 fathoms (Heezen 1957); they have occasionally been entangled in cables along the west coast of the Americas. Two entanglements are recorded in the history of the Alaska cable system: one occurred west of Baranof Island and the other off Vancouver; the latter involved a killer whale which became ensnarled in the cable at a depth of 563 fathoms (Fig. 3). But the mammal which poses the most serious threat to cables is man, who bruises and mauls cables with his anchors and fishing trawls.

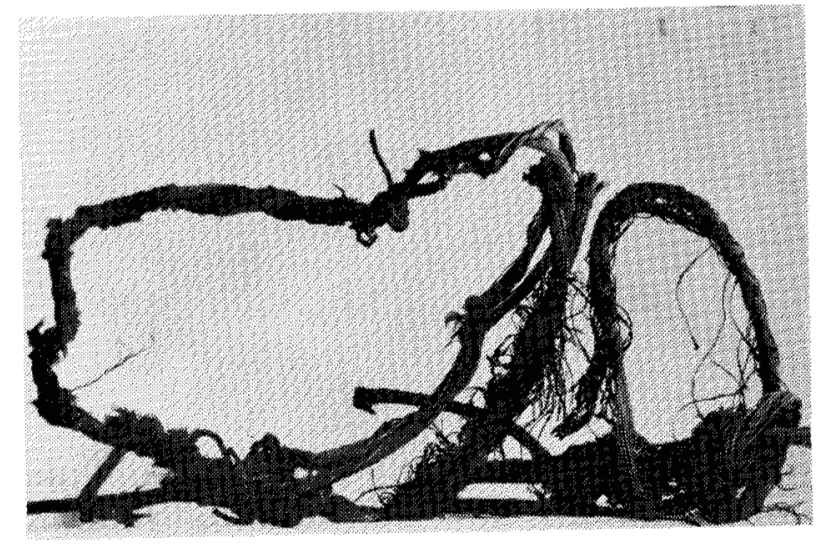

FIG. 3. Aftermath of whale entanglement in a submarine cable west of Vancouver Island.

CHAFE

On the Continental Shelf, currents scour the sea floor shifting and sifting the sands and gravels and transporting the clays and ooze to the greater depths beyond. Here chafe is the principal natural hazard to cables although in most parts of the world fishing gear and anchors are actually a greater threat. The Alaskan cables cross the Continental Shelf off Prince William Sound, off Chatham Strait, off Dixon Entrance, the southern end of the Alaska Panhandle and off Puget Sound. Chafe accounted for only 26 failures on the Shelf in a total of 400 miles of cable in 40 years.

Many of the communities within the inland waterways of the Alaska Panhandle were linked by cable, and within these many narrow straits currents abrading the sea floor heavily chafed the cables and caused the majority of the failures. Chafe was the principal factor in at least 100 cable interruptions. For example, the life of a cable on the rocky floor of the Valdez Narrows was 5 years, 
and in other straits the average intervals between failures was as little as 2 years. Chafing against the rock floor as well as sand-blasting by the current are effective agents in the narrow straits.

In the 10 years that the Aleutian cables were monitored, 13 failures occurred in 900 miles of cable and it was apparent that chafe by bottom currents was occurring on the slopes of the rocky volcanic islands. The short duration of cable maintenance does not allow any significant conclusions.

\section{SLUMPS AND TURBIDITY CURRENTS}

Many streams and a few larger rivers descend the mountain slopes dumping sediments into the canals, straits and channels of the Alaska Panhandle and into the bays of Prince William Sound. Alaska is within the circum-Pacific earthquake belt and in addition lies in the landward extension of the Mid-Oceanic Ridge earthquake belt. The high relief, the large quantities of sediment carried by the many streams, and the frequency of earthquakes to trigger movements result in many gravitational failures within sediment bodies. Slumps and turbidity cur-

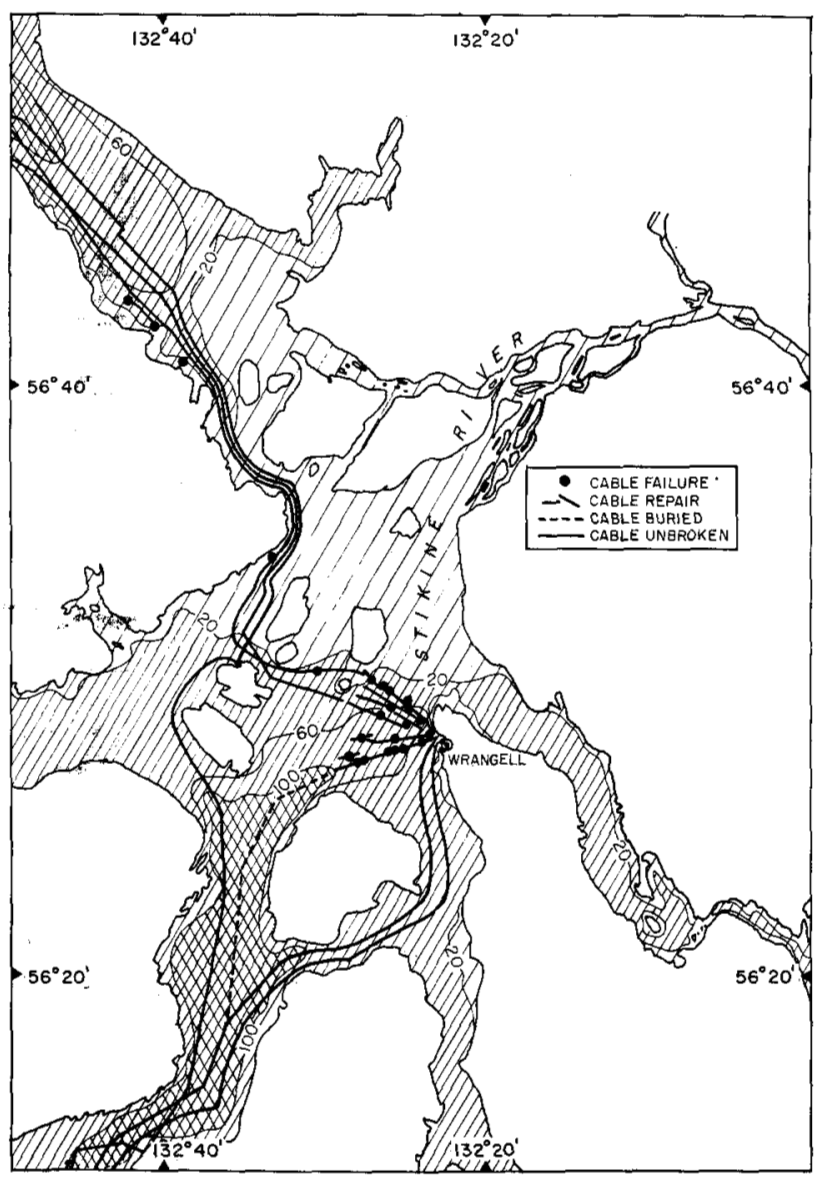

FIG. 4. Location of cable failures off the Stikine delta. 
rents are a serious threat to the cables and have accounted for at:least 40 failures in Alaskan waters (Heezen 1959).

A cable in the path of a slump or turbidity current is either broken under tension or buried beneath the deposit. Reports of tension failure; complete and sudden interruption and burial, generally refer to the results of gravitational failures of sediment accumulations (Heezen et al. 1966).

The deltas of each of the major rivers which enter the waterways along the routes of the Alaskan cables have been the source of slumps and turbidity currents which have repeatedly damaged the cables. The Stikine River which drains a $30,000 \mathrm{mi}^{2}$ area of the Stikine mountains has filled the glacially eroded valley within which it flows and has built a delta which nearly blocks the inland waterway (Fig. 4). The slope of the delta front is $1: 25$ between the 10 and 60 fathom curves (Fig. 5). Cables crossing the delta front have repeatedly failed under tension. For many years two cables lay along parallel routes across the delta front. In three instances both were broken the same day (Table I). On 21 August 1949 an earthquake resulted in multiple failures in two cables and burial of a third cable which lay farther from the delta on the flat floor of the channel. Over the 40 years in which cables monitored the Stikine delta, at least 14 slumps or turbidity currents sufficiently forceful to break cables occurred. The 4 triggered by earthquakes were most extensive.

Skagway lies at the northern end of a narrow water-filled tectonic trough which cuts deep into the continent (Fig. 6). The Skagway River is slowly filling this natural canal from the northern end. In 40 years of cable history only two disturbances off the Skagway River, both triggered by earthquakes, have been recorded (Table 1). A flow triggered by the 9 July 1958 earthquake (Tocher 1960) which ran southward from Skagway was augmented by slumps from the steep sides of the canal.

The Katzehin River which empties into the Lynn Canal from the east side has filled and nearly blocked the waterway. In this resulting shallow strait chafe is, as usual, a problem, but in addition slides and turbidity currents have in 6 instances flowed south along the canal interrupting the cables in its normal 100-fathom depths (Fig. 6). The cable repair log reports in each case burial and tension failure. However, in only one case ( 9 July 1958) did the failures follow an earthquake. The cable-repair ship in repairing the earthquake damage found at the southern end of the disturbance portions of cable ". . . piled up in bundłes. In one case 2.6 miles of cable were picked up in .9 of a mile. The cable was deeply buried, 18,00021,000 pounds being required to break it loose." On 1 December 1956 during a 75 m.p.h. gale the new telephone cable broke off the Katzehin River and one hour later the adjoining telegraph cable also failed.

The Lowe, Robe, and Valdez Rivers have built a broad delta into the eastern end of the 10-mile-long 130-fathom-deep Valdez Bay (Fig. 7). In 20 years failures on the delta front have broken the cables seven times (Table 1). In each case the cables were broken under tension and portions lying in the deeper parts of the bay were buried. Earthquake-triggered cable-damaging slumps broke the cables five times in 20 years. In the summer of 1921 and 1922 two failures not associated with earthquakes interrupted the Montague-Valdez cable on the delta front. The 


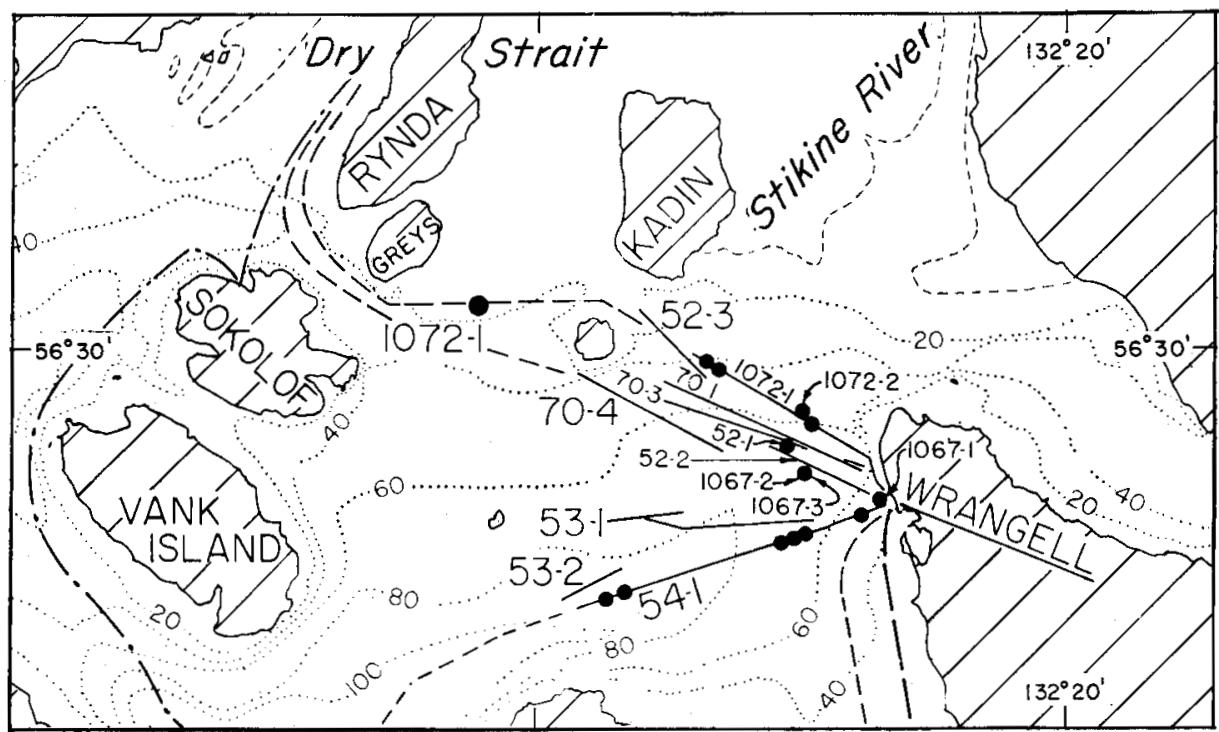

FIG. 5. Cable failures near the mouth of the Stikine River. Cable failure numbers refer to

Table 1. Cable 52: Cape Fanshaw-Wrangell, Cable 53: Hadley-Wrangell, Cable 54: Ketchikan-Wrangell, Cable 70: Petersburg-Wrangell, Cable 1067: Petersburg-Wrangell, Cable 1072: Petersburg-Wrangell.

TABLE 1. Cable repair data.

\begin{tabular}{|c|c|c|c|c|}
\hline $\begin{array}{l}\text { Cable } \\
\text { Failure } \\
\text { Number }\end{array}$ & $\begin{array}{l}\text { Date } \\
\text { of } \\
\text { Failure }\end{array}$ & $\begin{array}{l}\text { Date } \\
\text { of } \\
\text { Repair }\end{array}$ & $\begin{array}{l}\text { Depth } \\
\text { (fm.) }\end{array}$ & Reported Cause \\
\hline
\end{tabular}

APPROACHES TO WRANGELL (FIG. 5)

52-1 19 XI 20-XI'12

69

$52-2$

$6 \mathrm{VII}$

25-VII '13

20-68

53-1

6 VII

26-VII '13

73-83

$53-2$

$4 \mathrm{X}$

18-X'15

93-96

52-3*

52-4*

70-1

$21 \mathrm{X}$

19-X'15

28-IX'18

70-2*

$29 \mathrm{VI}$

7-VII' 23

70-3

27 IX

28-IV '23

11-X '23
Break, fault - "The fault originally was defective insulation about $71 / 2$ mi. from Wrangell, which was located by Mr. Bruck from that office; after this test a submarine landslide took place a little over a office; after this test a submarine landslide took place a little over a
mile from Wrangell, causing a total break, both ends of which are mile from Wrangell, causing a total break, both ends of which are
herewith submitted, showing evidence of instantaneous and violent fracture. My theory of this break 1 mile from Wrangell is that after the original fault was located, the mud from Stikine River continued pushing seaward and "carrying cable along with it until it broke." (Stout intermediate cable).

Breaks - "One $1 / 4$ mile from Wrangell cable house - broken conductor. Test located another broken conductor a mile distant - cable deeply buried, heavy heaving in strain. End came aboard, cable having broken under a sudden and violent strain, evidently caused by a submarine bottom slide."

Break - "Cable had broken under sudden severe strain, evidently submarine slide - broken cable deeply buried in bottom, not able to heave it in, were obliged to cut away, about 0.125 statute miles abandoned."

Break - "Cable end deeply buried. Cable has evidently been broken by a submarine slide."

Shore end diversion at Wrangell.

Break - "Cable having broken under a sudden heavy strain."

Break - " "Cable was broken by a submarine landslide. - end came aboard, evidently broken by sudden strain."

Wrangell shore end renewal.

Break - "Cable was broken by a submarine slide, which was cause of break in July this year. As the route over which cable was Jaid appeared to be an area of changing bottom, a new route as far away from former one as convenient, has been selected for cable used in this repair."

Break - "Cable was broken by submarine slide."

Wrangel shore end renewal. 


\begin{tabular}{|c|c|c|c|c|}
\hline $\begin{array}{l}\text { Cable } \\
\text { Failure } \\
\text { Numbert }\end{array}$ & $\begin{array}{l}\text { Date } \\
\text { of } \\
\text { Fallure }\end{array}$ & $\begin{array}{l}\text { Date } \\
\text { of } \\
\text { Repair }\end{array}$ & $\begin{array}{l}\text { Depth } \\
\text { (fm.) }\end{array}$ & Reported Cause \\
\hline $70-6^{*}$ & $24 X$ & 1-XI'27 & & $\begin{array}{l}\text { Break - "Submarine slide of debris and silt from the Stikine River, } \\
\text { which banks against cable at this point. Cable deeply buried. } 250 \text { nauts } \\
\text { abandoned." Cable looped to southward. }\end{array}$ \\
\hline 70 & $13 \mathrm{III}_{1929}$ to & $21 \cdot V^{\prime} 31$ & & Cable not in service. \\
\hline 70 & $\begin{array}{c}25 \mathrm{VII} \\
1938 \text { to }\end{array}$ & 1946 & & Cable not in service. \\
\hline 70-7* & & III' 46 & & New shore end. \\
\hline 1067-1 & 21 VIII & 30.VIII' 47 & 60 & Break - "Broken by strain during earthquake." \\
\hline 70 & & IX'47 & & $\begin{array}{l}\text { "Cable condition very poor. Used for telephone only. Repairs im- } \\
\text { practical due to heavy silt on top of cable making it impossible to } \\
\text { bring it to the surface without breaking it." }\end{array}$ \\
\hline $1067-2$ & & 14-IX '48 & 66 & Break - "Broken by strain .522 from Wrangell." \\
\hline 54-1 & 21 VIII & 30-IX '49 & $83-70$ & $\begin{array}{l}\text { Break - due to strain during earthquake. Breaks } 3.3, .27,3.0,1.2 \\
1.1 \text { and } 1.4 \text { nautical miles from Wrangell beach. Also one break } 4.8 \\
\text { nautical miles from Wrangell. Cable deeply buried. }\end{array}$ \\
\hline 1072-1 & 21 VIII & 30-VIII' 49 & & $\begin{array}{l}\text { Break - "Broken by strain during earthquake } 2.34, .12,2.26 \text { and } 1.1 \\
\text { miles from Wrangell beach." }\end{array}$ \\
\hline $1072-2$ & 9 VII '58 & & 60 & Break - earthquake. \\
\hline $1067-3$ & 9 VII '58 & & 60 & Break - Cable recovered. Was deeply buried in mud. \\
\hline
\end{tabular}

APPROACHES TO SKAGWAY (FIG. 6)

1086-1 9 VII' 58

45-1 $24 \times \quad 8-X I ' 27$

1087-1 1 XII'56
3 breaks - earthquake. Portion of cable recovered was deeply buried. At the southern extremity of splice the cable was piled up in bundles of 2.6 nauts of cable in .9 mile. The cable was also deeply buried $18,000-21,000$ lbs. being required to break it loose.

Break - "Submarine slide of silt and debris from Katzehin River which banks against the cable at this point. Cable so deeply buried were obligated to grapple east of Seduction Pt. in order to hook it." Break - Telegraph cable failures here usually occur at low tide. This occurred at high water during a wind storm of 70.75 m.p.h. Profile of cable route shows break well up in shoulder of delta.

Break.

Break - earthquake.

Break.

Breaks _ "There were 2 complete breaks in cable, each caused by a violent strain, one end on each break being deeply buried. The breaks were either caused by submarine slides, or accumulation of debris exerting pressure on cable."

Break - "Cable having been broken by a landslide - very heavy strain, cable evidently very deeply buried, tried to heave slowly and break cable out." Also in same vicinity a fault (core between armor wires in cable) removed.

Fault - "During the afternoon the damaged cable was p.u.; a landslide had evidently occurred causing a very heavy boulder to fall on cable severely bruising it and breaking some of the armor wires. This occurred in breaker zone at Haines. The fault occurred during a severe storm which caused a heavy surf to beat against the shore, undermining heavy boulders on the first point below Haines One of these these bould cres and grounding the cable. The whole shore line had been very much dis-
turbed during the storm, gravel and driftwood being piled bigh in some places."

Renewal Haines shore end.

Renewal of Haines cable landing. Break - anchor hook .5 off beach. Break - anchor hook .5 off Haines Beach.

Fault - cable badly kinked and bruised. Cable 46 was established by diverting cable No. 44 into Haines Mission. Entire cable was checked, picked up and checked for faults at this time.

Break and fault. Break due to submarine landslide about $1 / 2$ mile from Skagway. Cable deeply buried great difficulty in hooking. Were unable to hook except opposite Tanja Pt. Fault was caused by the conductor breaking inside insulation which frequently happens with rubber insulated cable.

Unable to find old cable so new one laid.

$100+$ Break - 1958 earthquake.

$80+150$ Break - 1958 earthquake. No further repairs - January 1960.

†Numeral after dash gives sequence of failure; e.g. 52-1 refers to the first failure of cable 52 .

"Failure is not plotted on the figure for the area; this can be for any of several reasons - the most common being that the failure is a trench line fallure, an anchor hook near shore or the position is not known with suficient accuracy to plot. 


\begin{tabular}{lllll}
\hline $\begin{array}{l}\text { Cable } \\
\text { Failure }\end{array}$ & $\begin{array}{l}\text { Date } \\
\text { of }\end{array}$ & $\begin{array}{l}\text { Date } \\
\text { of }\end{array}$ & $\begin{array}{l}\text { Depth } \\
\text { (fm.) }\end{array}$ & Reported Cause \\
Rumbert & Failure & Repair & & \\
\hline
\end{tabular}

The two anydrex cables lying between Haines and Skagway were broken at the same time as the coaxial cables ( 9 July 1958). These three cables were broken in the same manner by the movement of silt from the Skagway and Stikine rivers.

\begin{tabular}{|c|c|c|c|}
\hline $46-6$ & $1 \mathbf{X I}$ & $4-X I ' 15$ & $\begin{array}{l}\text { Fault - "The primary cause of fault was improper armoring, th } \\
\text { armor wire being imbedded in the insulation causing the same to wor } \\
\text { open. The ultimate cause of the rupture, and breaking of some strand } \\
\text { of the conductor, am unable to determine." This occurred at low wate } \\
\text { mark at Skagway. }\end{array}$ \\
\hline $46-7^{*}$ & & 14-VII'11 & Renewed Skagway shore end. \\
\hline $46-8^{*}$ & & $28-V^{\prime} 17$ & Diverted cable to new house at Skagway. \\
\hline $46-9 *$ & V & $14-V I I ' 20$ & Renewal Skagway cable landing. \\
\hline $46-10^{*}$ & & $15-\mathrm{VI}{ }^{\prime} 30$ & Break - Skagway cable landing. \\
\hline 45 & & & A new cable laid 19 May 1946 with no further repairs (Jan. 1960). \\
\hline 44 & & & Juneau to Skagway, no data. \\
\hline
\end{tabular}

APPROACHES TO VALDEZ (FIG. 7)

\begin{tabular}{|c|c|c|c|c|}
\hline $49-4$ & 4 II '08 & 29-II '08 & $129+79$ & $\begin{array}{l}\text { Break - earthquake - cable \#60 also broken. Each cable broken } \\
\text { twice. "The ends of two broken were recovered on each cable but had } \\
\text { to abandon a broken piece on each on account of cable being deeply } \\
\text { buried and impossible to raise." }\end{array}$ \\
\hline $60-2$ & $4 \mathrm{II}$ & 29-II '08 & $103+15$ & Earthquake $\longrightarrow 2$ breaks - see notes for cable 49 \\
\hline 49-5* & & 4-XI '09 & & Fault - cable fault under road about 60 feet from Valdez cable house. \\
\hline 50.1 & & $28-30-V ' 10$ & $10-105$ & $\begin{array}{l}\text { Faults - " } 3.124 \text { nautical miles out of a total length of } 3.492 \text { miles } \\
\text { had to be replaced } 2 \text { cable deeply buried - evidently buried glacial } \\
\text { deposits - fault } 150 \text { feet from able house caused by pick axe." }\end{array}$ \\
\hline $49-6$ & $11 \mathrm{IX}$ & 30-IX'11 & $115-98$ & $\begin{array}{l}\text { Break - earthquake - "The cable was broken by a submarine up- } \\
\text { heaval, and for } 2 \text { miles was completely buried. The lengths recovered } \\
\text { are so badly twisted as not to be fit for future use." }\end{array}$ \\
\hline $50-2 *$ & $17 \mathrm{XII}$ & $23-\mathrm{XII} ' 13$ & & $\begin{array}{l}\text { Break - "Both cable } 49+50 \text { broken off end of Valdez pier by Alameda } \\
\text { dragging her anchor." }\end{array}$ \\
\hline 50-3* & & 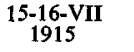 & & Fault - Fire at Valdez beach end. \\
\hline $60-3^{*}$ & $16 \times$ & $26-X^{\prime} 15$ & & Fault - Fire at Valdez shore end. \\
\hline $50-4^{*}$ & & $28-29-X^{\prime} 15$ & & Fault - Valdez beach end. \\
\hline $50-5^{*}$ & & $30-I X ' 16$ & & Fault — Valdez beach end. \\
\hline $60-4^{*}$ & $10 \mathrm{IX}$ & $13-X \cdot 17$ & & Fault - Anchor hook. \\
\hline $65-4$ & $28 X I$ & $10-\mathrm{XII}$ '20. & 95 & $\begin{array}{l}\text { Break — Earthquake — "Cable too deeply buried to continue heaving } \\
\text { in." Cable } 49 \text { broke same date. }\end{array}$ \\
\hline $49-7$ & $28 \times I$ & $8-X I I ' 20$ & 100 & $\begin{array}{l}\text { Break - Earthquake - "Cable having been broken by a sudden } \\
\text { violent strain. Cable deeply buried. Having crossed cable line without } \\
\text { hooking, hove up grapnel, a large tree trunk foul of grapnel." }\end{array}$ \\
\hline $60-5$ & 20 VIII & 29.VIII'21 & 95 & $\begin{array}{l}\text { Break - "Cause of interruption in cable \#60 unknown, probably, } \\
\text { caused by submarine landslide. Ends of break in cable not recovered." }\end{array}$ \\
\hline $60-6$ & & 29-VII '22 & 95 & $\begin{array}{l}\text { Fault - "This fault was probably due to a submarine earthslide which } \\
\text { so stretched the cable that it loosened a splice previously made in this } \\
\text { vicinity." }\end{array}$ \\
\hline $65-5$ & $23 \mathrm{II}$ & 6-III'25 & 76 & Breaks - Earthquake — same date as breaks to cable \#60. \\
\hline $60-7$ & $23 \mathrm{II}$ & $6-\mathrm{III}^{\prime} 25$ & 84 & Breaks - Both cable 60 and 65 were broken by an earthquake. \\
\hline
\end{tabular}

†Numeral after dash gives sequence of failure; e.g. 52-1 refers to the first failure of cable 52.

*Failure is not plotted on the figure for the area; this can be for any of several reasons - the most common being that the failure is a trench line failure, an anchor hook near shore or the position is not known with sufficient accuracy to plot.

4 February 1908 earthquake (Tarr and Martin 1912) broke the Valdez-Seward cable in four places three-eighths to one-and-a-half miles apart, while the ValdezSitka cable was broken in seven places five-eighths to seven-eighths of a mile apart. The earthquake of 21 September 1911 broke the Sitka-Valdez cable in exactly the same place as it failed in 1908 (Grant and Higgins 1913). Two miles were completely buried and those sections that were picked up were so badly twisted as to be unfit for further use. The operator at Valdez who was telegramming to Sitka at the time noticed that the failure occurred several seconds after the 


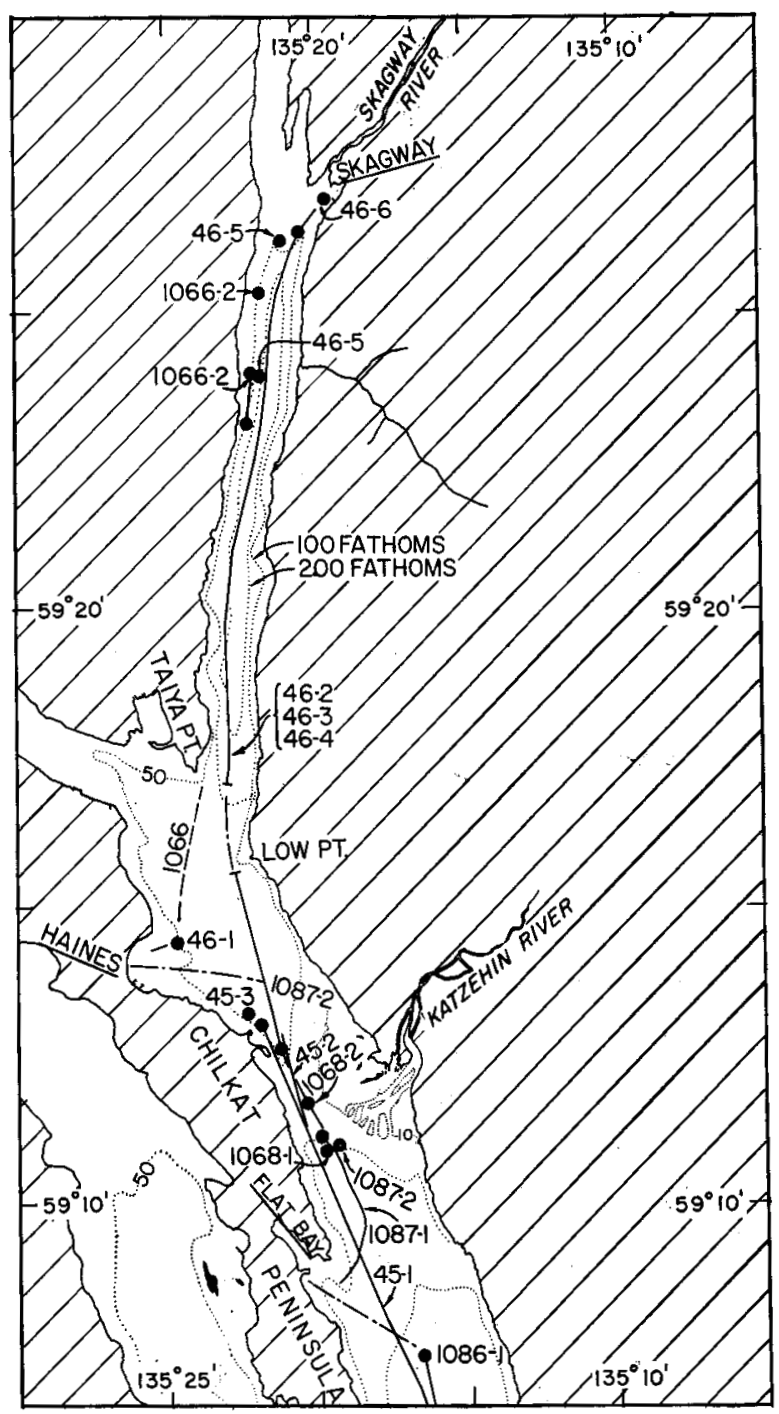

FIG. 6. Cable failures in Lynn Canal. Cable failure numbers refer to Table 1 . Cable 45: Juneau-Haines, Cable 46: Haines-Skagway, Cable 1068: Juneau-Haines-Sentinel Rock, Cable 1087: Flat Bay-Skagway (Telephone).

earthquake. During the earthquake of 23 February 1925 a portion of the Valdez dock collapsed and the board walk along Water Street was broken and distorted; both cables failed. The cables were abandoned before World War II. The 1964 Good Friday earthquake triggered a slide which carried away much of the Valdez waterfront. Nearly 100 million cubic yards of unconsolidated deposits were transported from the face of the delta front into the floor of the bay (Coulter and Migliaccio 1966).

Recent seismic reflection profiles in Valdez Bay reveal a sedimentary blanket with a maximum thickness of 800 metres overlying the glacially-gouged basement. The Quaternary sedimentary layers are locally crenulated especially near Valdez, suggesting subaqueous slumping, and west of Valdez, at the base of the slope, 


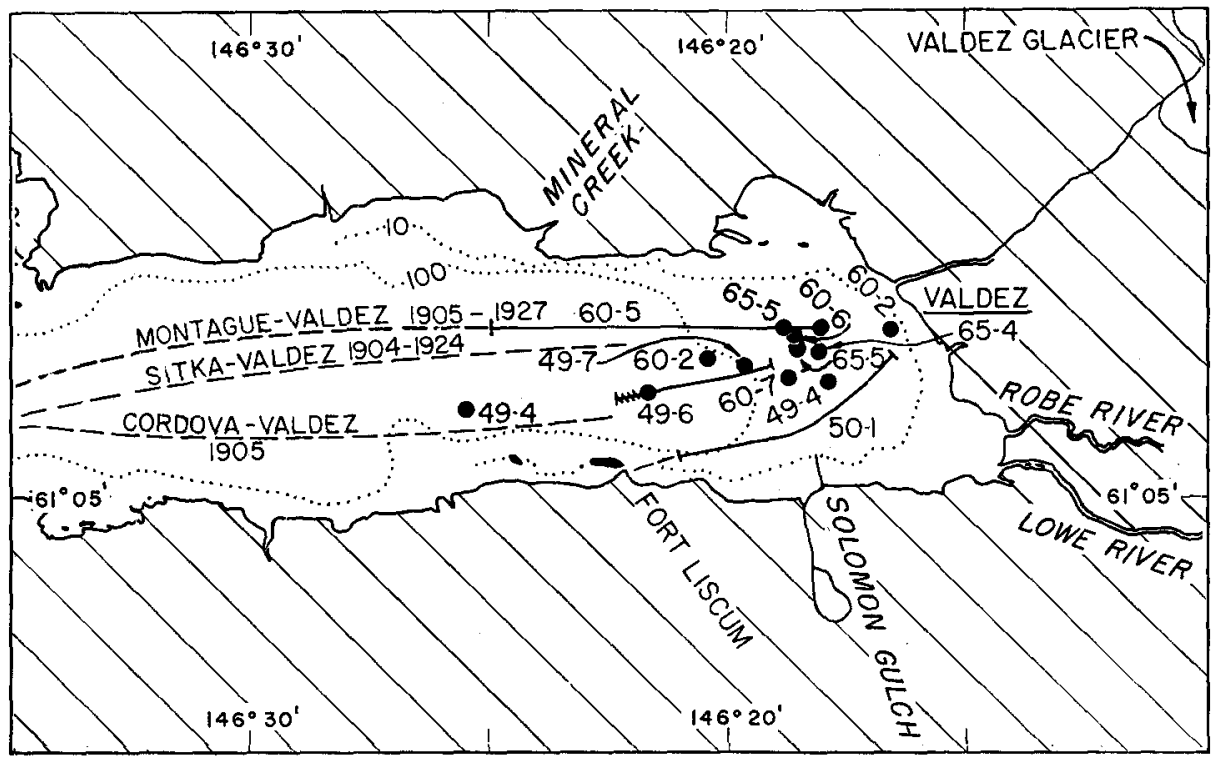

FIG. 7. Cable failures in Valdez Bay. Cable failure numbers refer to Table 1. Hachure marks indicate that a portion of the cable was abandoned.

a number of gentle irregularities up to 20 metres in relief are found. Precision echo sounding records on the slope reveal undulations resembling slump features (Von Huene et al. 1967). One might expect that approximately 2,000 individual beds on the average $45 \mathrm{~cm}$. thick should lie below the floor of Valdez Bay if slides and turbidity currents have occurred on the delta front throughout post-glacial times at the same rate as observed in this century. Such a thickness is necessary and sufficient to bring the cables beyond the reach of the grapnel and is not inconsistent with bedding thicknesses observed in ancient rocks.

In abyssal depths turbidities build up much more slowly and what was deposited in 10,000 years in Valdez Bay might take 100 million years in the abyss. At the mouths of the Congo and Magdelena rivers turbidity currents are triggered by the river itself at the rate of about 50 per century (Heezen 1956 and Heezen $e t$ al. 1964). Earthquakes have triggered the most severe of the delta front slides in Alaskan waters. The other slides may have been triggered by high winds or by the rivers themselves in flood. In the seismically active Valdez Bay, 5 of the 7 slides were caused by earthquakes; whereas off the Stikine River 10 of the 14 were triggered by forces other than earthquakes.

\section{CONTINENTAL SLOPE}

Cables which lie parallel to the continental slope and upper continental rise cross many individual canyons and are thus vulnerable to gravitational movements along a significant portion of their length. In addition, chafe occurs on the rocky slopes. A cable from Sitka to Valdez which was monitored for 20 years experienced 7 deep-water failures on the continental slope. In 1908 the cable 
failed in a submarine canyon off Cross Sound. The armour wires were found "much bruised" but did not break, however, the outer jute serving was chafed off for a distance of 4 miles. Only once did the cable break under tension. But in each of the other 6 interruptions the armour wires were damaged and the cable was chafed. A second parallel cable which for 40 years lay in deeper water on the upper continental rise never failed due to natural causes. Three of the cables linking Alaska and Washington which lie in 1,000 to 1,500 fathoms have had a nearly trouble-free history spanning 60 years. But one cable which lay in 500 to 1,000 fathoms experienced 13 faults in 20 years. Thus on the continental slope failures in the Sitka-Valdez and in the Sitka-Seattle cables apparently were not caused by turbidity currents, for if they had been, a similar number of failures would have been observed in the parallel deeper-lying cables. Thus the continental slope failures appear to be due to current chafe.

The topography of the continental slope of Alaska is poorly known but it seems likely that it will not turn out to be greatly different from the continental slope in similar areas of the world. The continental slope is characteristically indented by many small valleys and occasionally cut by a major canyon. In the relatively well-surveyed areas of California and New England 2 to 4 canyons occur each 100 miles. The deep-water cables of the Alaskan system have monitored approximately 1,000 miles of continental margin for nearly 50 years. They must cross at least $\mathbf{4 0}$ major canyons but they have never failed because of a turbidity current. The interval between turbidity currents coursing Alaskan submarine canyons must at present be greater than 2,000 years and it is quite possible that none has occurred in the last 5,000 years.

\section{ACKNOWLEDGEMENTS}

The preparation of this report was supported by the Bell Telephone Laboratories. The cable failure data were supplied by Maude H. Regman of the Alaskan Communication System, and from personal communication with Capt. John Bowen, former master of the Cable Ship Basil $O$. Lenoir. During the preparation of this report, the writers were aided by R. C. Allen, L. Snoke, A. Hale and Mark Campbell of Bell Telephone Laboratories.

\section{REFERENCES}

COULTER, H. W. and R. R. Migliaccio. 1966. Effects of the Earthquake of March 27, 1964, at Valdez, Alaska. U.S. Geological Survey Professional Paper 542 C. 36 pp.

GRANT, U. S. and D. F. HIGgINs. 1913. Coastal Glaciers of Prince William Sound and Kenai Peninsula, Alaska. U.S. Geological Survey Bulletin 526. 72 pp.

HEEZEN, B. C. 1956. Corrientes de turbidez del Rio Magdelena. Boletin Sociedad Geographia Colombia, 51, 52: 135-43.

1957. Whales entangled in deep-sea cables. Deep-Sea Research, 1: 105-15.

1959. Dynamic processes of abyssal sedimentation. The Geophysical Journal of the Royal Astronomical Society, 2: 142-63.

HEEZEN, B. C., M. EWING and G. L. JOHNSON. 1966. The Gulf of Corinth Floor. Deep-Sea Research, 13: 381-411. 
* HEezen, B. C. and G. L. JoHnson. 1966. Cable Failures in the Alaska Cable System. Prepared by Lamont Geological Observatory for the Bell Telephone Laboratories, New Jersey, $170 \mathrm{pp}$.

HEEZEN, B. C., R. J. MENZIES, E. SCHNEIDER, M. EWING and N. C. GRANELli. 1964. Congo Submarine Canyon. Bulletin of the American Association of Petroleum Geologists, 48: 1126-49.

TARR, R. S. and L. MARTIN. 1912. The Earthquakes at Yakatat Bay, Alaska, in September, 1899. U.S. Geological Survey Professional Paper 69. $135 \mathrm{pp}$.

TOCHER, D. 1960. The Alaskan earthquake of July 10, 1958. Bulletin of the Seismological Society of America, 50(2): 217-20.

VON HUENE, R., G. G. SHOR and E. REIMNITZ. 1967. Geological interpretation of seismic profiles in Prince William Sound, Alaska. Geological Society of America Bulletin, 78: 259-68.

* Available at the Library of the Arctic Institute of North America, 3458 Redpath Street, Montreal 109, P.Q., Canada. 